\title{
ANALISIS KESALAHAN BERBAHASA PADA PENULISAN MEDIA LUAR RUANG DI PANYABUNGAN
}

Oleh:

\author{
Nikmah Sari Hasibuan
}

Email : nikmah.sari@um-tapsel.ac.id

Universitas Muhammadiyah Tapanuli Selatan

\begin{abstract}
ABSTRAK
Penelitian ini bertujuan untuk menganalisis kesalahan berbahasa pada penulisan media luar ruang di Panyabungan dan memperbaiki kesalahan berbahasa tersebut sesuai dengan kaidah bahasa Indonesia. Metode penelitian yang digunakan penulis adalah penelitian deskriptif kualitatif yaitu mendeskripsikan tulisan-tulisan pada media luar ruang kemudian dianalisis kesalahan penulisannya dan memperbaiki tulisan tersebut. Objek dalam penelitian ini adalah media luar ruang di Panyabungan Kabupaten Mandailing Natal. Penelitian ini dilaksanakan hanya berdasarkan fakta sebagaimana yang ada dilapangan. Berdasarkan hasil penelitian dari hasil analisis data-data media luar ruang di Panyabungan dapat disimpulkan bahwa masih banyak kesalahan-kesalahan penulisan yang terdapat pada media luar ruang tersebut. Bentuk-bentuk kesalahan tersebut berupa diksi/pilihan kata yang kurang tepat, semantik/pemaknaan kata yang tidak pada tempatnya ejaan yang salah seperti tanda baca, pemakaian huruf kapital, penulisan singkatan, garis miring dan lain-lain, dan masih banyak kesalahan yang ditemukan dilapangan.
\end{abstract}

Kata Kunci: Anakes, Media Luar Ruang, Panyabungan.

\section{A. PENDAhULUAN}

Bahasa merupakan alat komunikasi yang digunakan oleh manusia untuk menyampaikan informasi baik lisan maupun tulisan. Bahasa juga digunakan untuk mengungkapkan ide, gagasan, pikiran, konsep, dan perasaan. Untuk menyampaikan ide, gagasan, pikiran dan perasaan tentu harus menggunakan bahasa yang baik agar orang orang lain dapat mengerti akan informasi yang akan kita sampaikan. Bahasa yang baik adalah bahasa yang komunikatif sesuai dengan kaidah kebahasaan teruama menyampaikan sebuah informasi.

Penulisan dalam media luar ruang yang tidak sesuai dengan kaidah bahasa Indonesia masih banyak dijumpai di wilayah Mandailing Natal. Beberapa kesalahan yang terdapat media luar ruang tersebut didapati beberapa kesalahan mulai dari penggunaan kalimat yang 
tidak efektif, diksi (pilihan kata) yang tidak tepat, sampai dengan pengguanaan ejaan yang salah, bahasa asing. Berdasarkan kesalahan-kesalahan penulis bermaksud untuk menganalisis kesalahan-kesalahan berbahasa pada media luar ruang di wilayah Mandailing Natal. Objek penelitiannya adalah penulisan pada papan nama pertokoan, papan nama instansi, baliho, dan spanduk yang ada di wilayah Mandailing Natal. Peneliti memilih wilayah Mandaiing Natal sebagai tempat penelitian karena berdasarkan tempat tinggal dan kesalahan penulisan papan nama pertokoan, papan nama instansi, baliho, dan spanduk masih banyak dijumpai di wilayah ini. Untuk itu, peneliti tergerak untuk meneliti kesalahan pada media luar ruang yang nantinya hasil penelitian ini dapat berguna bagi masyarakat umum tekhusus penulis yang ingin menginformasikan sesuatu lewat tulisan dan menjadi bahan ajar berbentuk modul dalam mata kuliah analisis kesalahan berbahasa yang diemban sendiri oleh peneliti.

Alasan pemilihan penulisan pada media luar ruang di wilayah ini sebagai data penelitian, yaitu pertama media luar ruang seperti baliho dan spanduk lebih mudah ditemukan dibandingkan media elektronik. Kedua, rentang waktu pemasangannya lebih lama. Ketiga, media luar ruang menjangkau semua lapisan masyarakat karena pemasangannya dilakukan sampai ke pelosok daerah. Keempat, penelitian terhadap media luar ruang di wilayah Mandailing Natal belum pernah dilakukan.

\section{B. KAJIAN TEORI}

\section{Analisis Kesalahan Berbahasa}

Kesalahan berbahasa merupakan sebuah penyimpangan bahasa yang dipergunakan baik itu tata bahasa-nya, ejaannya, sintaksis, maupun makna/semantik bahasa itu sendiri. Kesalahan berbahasa biasanya digunakan/diapakai oleh orang yang mempelajari bahasa kedua. (Tarigan dalam Susanti, 2014:27). terdapat dua ukuran dalam mendefenisikan kesalahan ber-bahasa, yaitu:

(1) Berkaitan dengan faktor-faktor penentu dalam berkomunikasi. Faktor-faktor penentu dalam berkomunikasi itu adalah: siapa yang berbahasa dengan siapa, untuk tujuan apa. Dalam situasi apa (tempat dan waktu), dalam konteks apa (peserta lain, kebudayaan, dan suasana), dengan jalur apa (lisan atau tulisan), dengan media apa (tatap muka, telepon, surat, kawat, buku, koran, dan sebagainya), dalam peristiwa apa 
(bercakapcakap, ceramah, upacara, laporan, lamaran, kerja, pernyataan cinta, dan sebagainya).

(2) Berkaitan dengan aturan atau kaidah kebahasaan yang dikenal dengan istilah tata bahasa (Depdikbud dalam Setyawati, 2010:14-15). Jadi, kesimpulannya bahwa kesalahan berbahasa adalah penggunaan bahasa baik secara lisan maupun tertulis yang menyimpang dari faktor-faktor penentu berkomunikasi atau menyimpang dari norma kemasyarakatan dan menyimpang dari kaidah tata bahasa Indonesia.

Menurut Tarigan (Setyawati, 2010:19-20), kesalahan berbahasa dalam bahasa Indonesia dapat diklarifikasikan menjadi:

(1) berdasarkan tataran linguistik, kesalahan berbahasa dapat diklarifikasikan menjadi: kesalahan berbahasa dibidang fonologi, morfologi, sintaksis (frasa, klausa, kalimat), semantik, dan wacana;

(2) berdasarkan kegiatan berbahasa atau keterampilan berbahasa dapat diklarifikasikan menjadi kesalahan berbahasa dalam menyimak, berbicara, membaca, dan menulis;

\section{Ejaan}

Ejaan adalah seperangkat aturan atau kaidah pelambangan bunyi bahasa, pemisahan, penggabungan, dan penulisannya dalam suatu bahasa. Ejaan mengatur keseluruhan cara menuliskan bahasa dengan menggunakan huruf, kata, dan tanda baca sebagai sarananya (Susanti, 2014:28). Pemakaian Huruf Kapital

Berdasarkan Pedoman Umum Ejaan Bahasa Indonesia ada aturan dalam penggunaan huruf kapital (Kemendikbud, 2016:5-13), yaitu sebagai berikut.

1. Huruf kapital dipakai sebagai huruf pertama awal kalimat

2. Huruf kapital dipakai sebagai huruf pertama unsur nama orang, termasuk julukan.

3. Huruf kapital dipakai pada awal kalimat dalam petikan langsung.

4. Huruf kapital dipakai sebagai huruf pertama unsur nama gelar kehormatan, keturunan, keagamaan, atau akademik yang diikuti nama orang, termasuk gelar akademik yang mengikuti nama orang.

(1) Pemakaian Huruf Miring

Berdasarkan Pedoman Umum Ejaan Bahasa Indonesia ada tiga aturan dalam penggunaan huruf miring (Kemendikbud, 2016:13-14), yaitu sebagai berikut. 
1. Huruf miring dipakai untuk menuliskan judul buku, nama majalah, atau nama surat kabar yang dikutip dalam tulisan, termasuk dalam daftar pustaka.

2. Huruf miring dipakai untuk menegaskan atau mengkhususkan huruf, bagian kata, kata, atau kelompok kata dalam kalimat.

(2) Gabungan Kata

Berdasarkan Pedoman Umum Ejaan Bahasa Indonesia ada aturan dalam penggunaan huruf miring (Kemendikbud, 2016:19-20), yaitu sebagai berikut.

1. Unsur gabungan kata yang lazim disebut kata majemuk, termasuk istilah khusus, ditulis terpisah.

2. Gabungan kata yang dapat menimbulkan salah pengertian ditulis dengan membubuhkan tanda hubung (-) di antara unsur-unsurnya.

(3) Akronim

Akronim ialah singkatan yang berupa gabungan huruf awal, gabungan suku kata, maupun gabungan huruf, fan suku kata dari deret yang diperlukan sebagai kata. Berdasarkan Pedoman Umum Ejaan Bahasa Indonesia ada tiga aturan dalam penggunaan akronim (Kemendikbud, 2016:28-29), yaitu sebagai berikut.

1. Akronim nama diri yang terdiri atas huruf awal setiap kata ditulis dengan huruf kapital tanpa tanda titik.

2. Akronim nama diri yang berupa gabungan suku kata atau gabungan huruf dan sukku kata dari deret kata ditulis dengan huruf awal kapital.

(4) Pemakaian Tanda Baca

a. Tanda Titik (.)

Berdasarkan Pedoman Umum Ejaan Bahasa Indonesia ada beberapa aturan salah satunya tanda titik dipakai pada akhir kalimat pernyataan (Kemendikbud, 2016:36)

b. Tanda Koma (,)

Berdasarkan Pedoman Umum Ejaan Bahasa Indonesia ada beberapa aturan dalam penggunaan tanda koma (Kemendikbud, 2016:39-44), yaitu sebagai berikut.

a) Tanda koma dipakai di antara unsur unsur dalam suatu pemerincian atau pembilangan. 
b) Tanda koma dipakai di antara (a) nama dan alamat, (b) bagian-bagian alamat, (c) tempat dan tanggal, serta (d) nama tempat dan wilayah atau negeri yang ditulis berurutan.

\section{c. Tanda Garis Miring}

Berdasarkan Pedoman Umum Ejaan Bahasa Indonesai ada beberapa tiga aturan dalam penggunaan tanda garis miring (Kemendikbud, 2016:55-56), yaitu sebagai berikut.

a) Tanda garis miring dipakai dalam nomor surat, nomor pada alamat, dan penandaan masa satu tahun yang terbagi dalam dua tahun takwim.

b) Tanda garis miring dipakai sebagai peng-ganti kata dan, atau, serta setiap.

\section{Diksi}

Ketepatan adalah kemampuan sebuah kata untuk menimbulkan gagasan yang sama pada imajinasi pembaca atau pendengar, seperti yang dipikirkan atau dirasakan oleh penulis atau pembicara. selanjutnya, baik berupa aksi verbal maupun nonverbal dari pembaca atau pendengar. Selain itu, ketepatan juga tidak akan menimbulkan kesalah-pahaman antara kedua pihak yang sedang berkomunikasi.

Secara umum, persyaratan pilihan kata, meliputi (1) ketepatan, (2) kelaziman, (3) kecermatan (Keraf, 2002: 88). Beberapa butir perhatian dan persoalan berikut ini hendaknya diperhatikan setiap orang agar bisa mencapai ketepatan pilihan kata, yaitu:

1) Membedakan secara cermat denotasi dan konotasi.

2) Membedakan secara cermat kata-kata yang hampir bersinonim

3) Membedakan kata-kata yang mirip dalam ejaannya

4) Membedakan kata umum dan kata khusus

\section{Metode Penelitian}

Metode penelitian yang digunakan penulis adalah penelitian deskriptif kualitatif yaitu mendeskripsikan tulisan-tulisan pada media luar ruang kemudian dianalisis kesalahan penulisannya dan memperbaiki tulisan tersebut. Penelitian ini dilaksanakan hanya berdasarkan fakta sebagaimana yang ada dilapangan. Objek dalam penelitian ini adalah media luar ruang di Panyabungan Kabupaten Mandailing Natal. 


\section{Hasil Penelitian}

Berikut data-data kesalahan bahasa Indonesia pada penulisan media luar ruang yaitu pada spanduk, papan nama, baliho, dan lainnya.

\section{Korpus Data}

Tabel 1 Aspek Kesalahan Penggunaan Ejaan

\begin{tabular}{|c|c|}
\hline No. & Data Kesalahan \\
\hline 1. & $\begin{array}{l}\text { LILY BUTIK } \\
\text { MENJUAL PAKAIAN MUSLIM \& } \\
\text { SYAR'I } \\
\text { Jl. Williem Iskandar Sipolu - Polu } \\
\text { Panyabungan }\end{array}$ \\
\hline 2. & $\begin{array}{l}\text { Kipang Pulut Asli } \\
\text { DIAN } \\
\text { Enak, Gurih,_Tanpa Pengawet } \\
\text { Oleh-oleh Has Panyabungan }\end{array}$ \\
\hline 3. & $\begin{array}{l}\text { Selamat Menjalankan } \\
\text { Ibadah Puasa } \\
\text { Mari Jaga Kesucian } \\
\text { Bulan Ramadhan 1440H/2019M } \\
\text { Dengan Bingkai Persatuan dan } \\
\text { kedamaian }\end{array}$ \\
\hline 4. & $\begin{array}{l}\text { APOTEK } \\
\text { Semangat Baru } \\
\text { JL.Willem Iskandar_Sipolu-Polu } \\
\text { Panyabungan }\end{array}$ \\
\hline 5. & $\begin{array}{l}\text { PRAKTEK DOKTER GIGI } \\
\text { Drg. ALDELINA NST } \\
\text { SIP. NO. } 440 / 3036 / \text { DINKES / } \\
2014 \\
\text { PAGI }: 10.00 \_12.00 \mathrm{WIB} \\
\text { SORE : } 16.00 \_20.00 \mathrm{WIB} \\
\text { HARI : } \quad \text { TUTUP }\end{array}$ \\
\hline 6. & $\begin{array}{l}\text { JAYANA MOTOR } \\
\text { JUAL BELI SEPEDA MOTOR } \\
\text { BARU \& BEKAS } \\
\text { CASH DAN KREDIT } \\
\text { JL. WILLEM ISKANDAR } \\
\text { PANYABUNGAN }\end{array}$ \\
\hline 7. & $\begin{array}{l}\text { KANTOR CABANG } \\
\text { PT. PADANG CITRA MANDIRI }\end{array}$ \\
\hline
\end{tabular}




\begin{tabular}{|c|c|}
\hline & $\begin{array}{l}\text { Melayani Penjualan Tiket Pesawat } \\
\text { ON-LINE } \\
\text { DOMESTIC \& INTERNATIONAL } \\
\text { Alamat: JLn. WILLEM ISKANDER } \\
\text { NO_210 SIPOLU-POLU } \\
\text { PANYABUNGAN HP 0813-6144- } \\
2922\end{array}$ \\
\hline 8. & $\begin{array}{l}\text { HJ. NURAIDAH LBS } \\
\text { MENJUAL: Pakaian Pengantin, } \\
\text { Sprai, Pelekat_\& Busana Muslim } \\
\text { SIMPANG LINTAS } \\
\text { BARAT/PASAR BARU/SIPOLU- } \\
\text { POLU_PANYABUNGAN_MADINA }\end{array}$ \\
\hline 9. & $\begin{array}{l}\text { TUKANG MAS } \\
\text { SINAR ABADI } \\
\text { ILHAMUDDIN } \\
\text { BIN H.SAHBAN DARWIS } \\
\text { PASAR BARU LINTAS BARAT } \\
\text { PANYABUNGAN }\end{array}$ \\
\hline 10. & $\begin{array}{l}\text { MADISON Boutique } \\
\text { JALAN SIBAROAR LINTAS } \\
\text { BARAT NO. 4_PANYABUNGAN }\end{array}$ \\
\hline
\end{tabular}

Table 2 Aspek Kesalahan Diksi

\begin{tabular}{|l|l|}
\hline No. & \multicolumn{1}{|c|}{ Data Kesalahan } \\
\hline 1. & $\begin{array}{l}\text { LILY BUTIK } \\
\text { MENJUAL PAKAIAN MUSLIM \& } \\
\text { SYAR'I } \\
\text { Jl. Williem Iskandar Sipolu - Polu } \\
\text { Panyabungan }\end{array}$ \\
\hline 2. & $\begin{array}{l}\text { Kipang Pulut Asli } \\
\text { DIAN } \\
\text { Enak, Gurih,_Tanpa Pengawet } \\
\text { Oleh-oleh Has Panyabungan }\end{array}$ \\
\hline 3. & $\begin{array}{l}\text { JAYANA MOTOR } \\
\text { JUAL BELI SEPEDA MOTOR } \\
\text { BARU \& BEKAS } \\
\text { CASH DAN KREDIT } \\
\text { JL. WILLEM ISKANDAR } \\
\text { PANYABUNGAN }\end{array}$ \\
\hline
\end{tabular}




\begin{tabular}{|c|c|}
\hline 4. & $\begin{array}{l}\text { KANTOR CABANG } \\
\text { PT. PADANG CITRA MANDIRI } \\
\text { Melayani Penjualan Tiket Pesawat } \\
\text { ON-LINE } \\
\text { DOMESTIC \& INTERNATIONAL } \\
\text { Alamat: JLn. WILLEM ISKANDER } \\
\text { NO_210 SIPOLU-POLU } \\
\text { PANYABUNGAN HP 0813-6144- } \\
2922\end{array}$ \\
\hline 5. & $\begin{array}{l}\text { TUKANG } \underline{\text { MAS }} \\
\text { SINAR ABADI } \\
\text { ILHAMUDDIN } \\
\text { BIN H.SAHBAN DARWIS } \\
\text { PASAR BARU LINTAS BARAT } \\
\text { PANYABUNGAN }\end{array}$ \\
\hline 6. & $\begin{array}{l}\text { MADISON Boutique } \\
\text { JALAN SIBAROAR LINTAS } \\
\text { BARAT NO. } 4 \text { PANYABUNGAN }\end{array}$ \\
\hline 7. & $\begin{array}{l}\text { ERMY GORDYN } \\
\text { DESIGNINTERIOR }\end{array}$ \\
\hline
\end{tabular}

\section{Deskripsi Penggunaan Bahasa dalam Baliho, Spanduk, dan Papan Nama}

\section{Data 1}

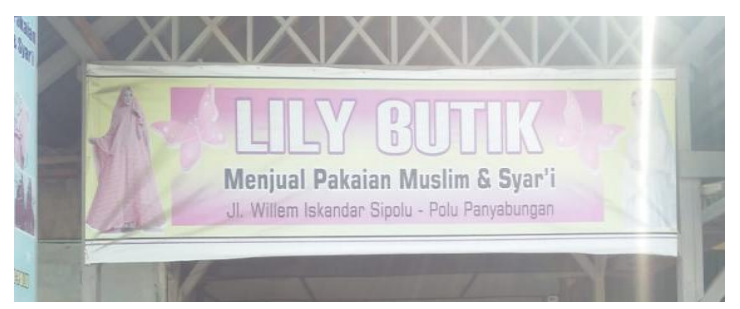

(1a) *LILY BUTIK

MENJUAL PAKAIAN MUSLIM \& $\underline{\text { SYAR'I }}$

Jl. Williem Iskandar Sipolu - Polu Panyabungan

Penulisan konstruksi tersebut mempunyai tiga kesalahan. Pertama, penulisan kata syar'i yang mengandung unsur serapan dari bahasa asing yaitu bahasa arab yang tidak sesuai dengan kaidah bahasa Indonesia yaitu ada tanda petik satu diatas setelah huruf $r$, karena berdasarkan Pedoman Umum Ejaan Bahasa Indonesia unsur asing yang penulisan dan pengucapannya disesuaikan dengan kaidah bahasa Indonesia (Kemendikbud, 2016:58). Perbaikannya adalah dengan menghilangkan tanda petik satu diantara katanya. Kesalahan yang kedua adalah tidak 
adanya tanda koma pada penulisan alamat papan nama toko yaitu antara nama jalan dan tempatnya. Seharusnya tanda koma diletakkan sesudah nama jalan kemudian dilanjutkan nama tempat karena tanda koma dipakai di antara (a) nama dan alamat, (b) bagian-bagian alamat, (c) tempat dan tanggal, serta (d) nama tempat dan wilayah atau negeri yang ditulis berurutan (Kemendikbud, 2016 : 42). Kesalahan yang ketiga adalah adanya spasi/jarak antara kata yang mengandung unsur ulang dengan tanda hubungnya, kata ulang tidak ditambahkan spasi lagi karena sudah adal tanda hubung yang menghubngkan kakta ulang tersebut. Hal ini berdasarkan Pedoman Ejaan Bahasa Indonesia, bentuk ulang ditulis dengan menggunakan tanda hubung (-) di antara unsur-unsurnya.

Perbaikannya adalah sebgai berikut.

(1b) LILY BUTIK

Menjual Pakaian Muslim \& Syar i

Jl. Williem Iskandar, Sipolu-Polu, Panyabungan.

\section{Data 2}

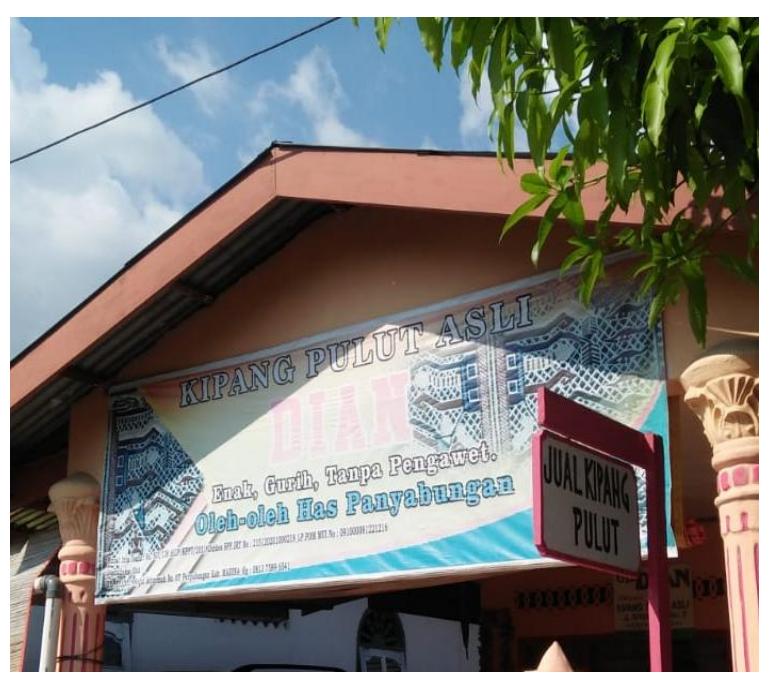

(2a) *Kipang Pulut Asli

\section{DIAN}

Enak, Gurih,_,Tanpa Pengawet

Oleh-oleh $\underline{\text { Has }}$ Panyabungan

Pada konstruksi tersebut terdapat tiga kesalahan dalam penulisannya. Kesalahan yang pertama adalah tidak adanya kata dan diantara kata tanpa dan gurih, seharusnya kata dan disisipkan sebelum unsur terakhir. Kesalahan yang kedua adalah digunakannya huruf kecil 
pada kata oleh, seharusnya diagunakan huruf kapital karena semua kata yang terdapat pada papan nama toko tersebut adalah huruf besar disetiap awal katanya, karena huruf kapital dipakai sebagai huruf pertama semua kata (termasuk semua unsur bentuk ulang sempurna) dalam nama negara, lembaga, badan, organisasi, atau dokumen, kecuali kata tugas, seperti $d i$, ke, dari, dan, yang, dan untuk (Kemendikbud, 2016:11). Kesalahan yang ketiga yaitu kata Has yang tidak memiliki huruf $k$ diawal katanya, seharusnya dalam penulisan kata harus sesuai dengan KBBI yaitu dengan menambahkan huruf k diawal katanya.

Perbaikannya adalah sebagai berikut.

(2b) Kipang Pulut Asli

DIAN

Enak, Gurih, dan Tanpa Pengawet

Oleh-Oleh Khas Panyabungan

\section{Data 3}

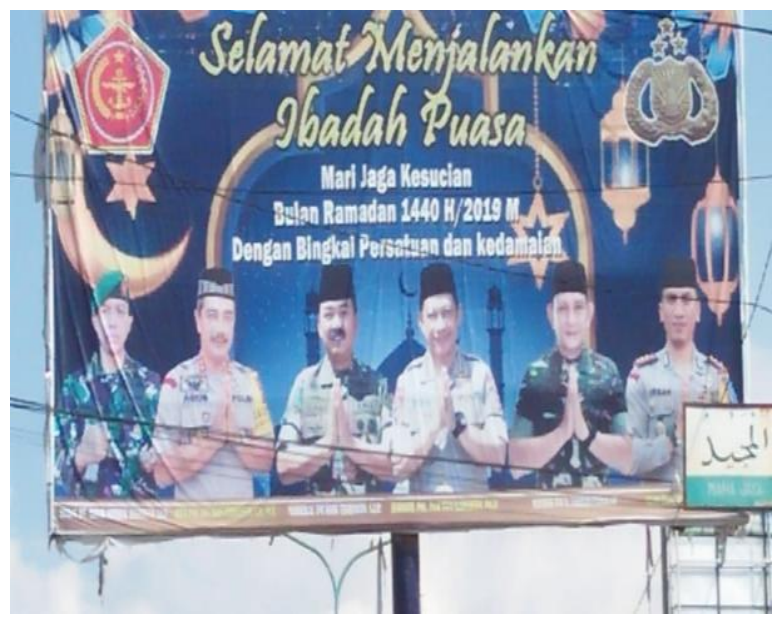

(3a) *Selamat Menjalankan

Ibadah Puasa

Mari Jaga Kesucian

Bulan Ramadhan 1440H/2019M

Dengan Bingkai Persatuan dan kedamaian

Konstruksi tersebut mempunyai kesalahan di kata kedamaian yang huruh diawal katanya menggunakan huruf kecil. Seharusnya diubah menjadi huruf besar karena semua kata dalam 
kalimat tersebut menggunakan huruf besar diawal katanya karena huruf kapital dipakai sebagai huruf pertama semua kata (termasuk semua unsur bentuk ulang sempurna) dalam nama negara, lembaga, badan, organisasi, atau dokumen, kecuali kata tugas, seperti $d i$, $k e$, dari, dan, yang, dan untuk (Kemendikbud, 2016:11)

Perbaikannya adalah sebagai berikut.

(3b) Selamat Menjalankan

Ibadah Puasa

Mari Jaga Kesucian

Bulan Ramadhan 1440H/2019M

Dengan Bingkai Persatuan dan Kedamaian

\section{Data 4}

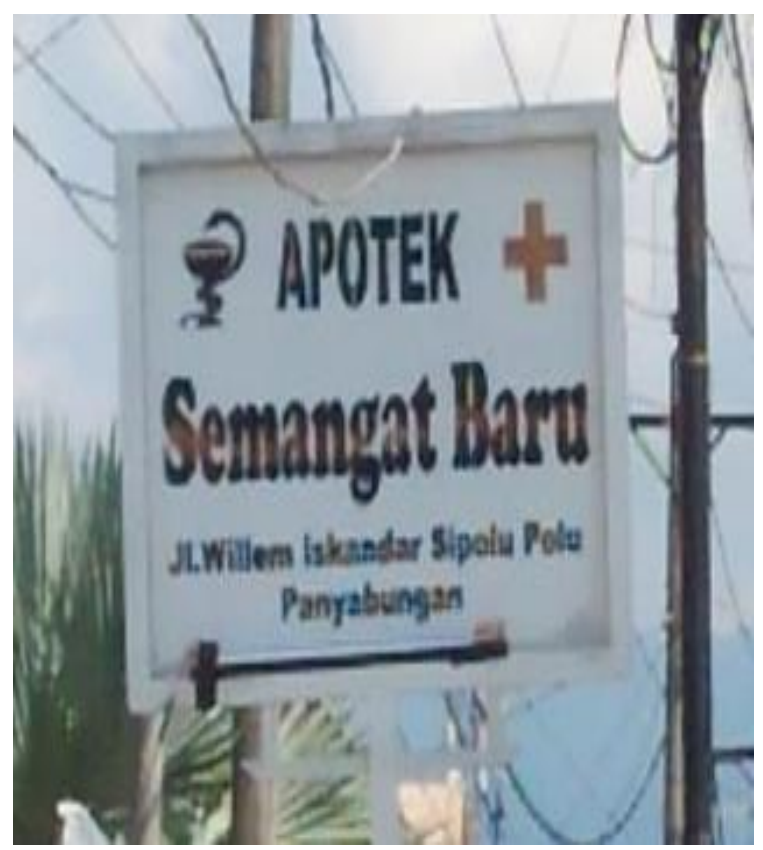

(4a) *APOTEK

Semangat Baru

JL.Willem Iskandar_Sipolu-Polu

Panyabungan

Konstruksi tersebut mempunyai tiga kesalahan dalam penulisannya. Kesalahan yang pertama adalah adanya huruf kapital dalam singkatan $J L$ yaitu huruf $l$. Seharusnya singkatan tersebut 
dibuat huruf kecil dengan diawal kata huruf kapital karena seluruh kata dalam kalimat tersebu hanya menggunakan huruf besar diawal katanya. Kesalahan yang kedua yaitu tidak adanya spasi setelah tanda titik singkatan $J L$. Seharusnya spasi disisipkan setelah tanda titik hal ini berdasarkan kaidah ejaan, spasi digunakan setelah tanda seru, tanda tanya, dan tanda titik untuk memulai kalimat baru. Kesalahan yang ketiga yaitu tidak adanya tanda koma sebagai pemisah antara nama jalan dan wilayah tempat toko. Seharusnya tanda koma diletakkan diantara bagian-bagian alamat karena tanda koma dipakai di antara (a) nama dan alamat, (b) bagian-bagian alamat, (c) tempat dan tanggal, serta (d) nama tempat dan wilayah atau negeri yang ditulis berurutan (Kemendikbud, $2016: 42$ ).

Perbaikannya adalah sebagai berikut.

\section{APOTEK}

Semangat Baru

Jl. Willem Iskandar, Sipolu-Polu

Panyabungan

\section{Data 5}

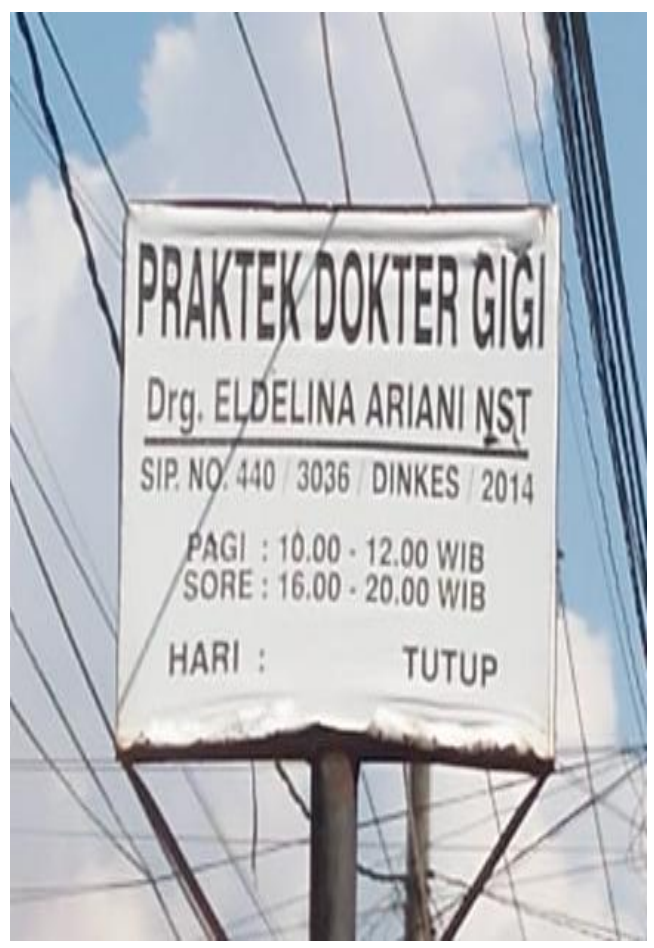


(5a) *PRAKTEK DOKTER GIGI

Drg. ALDELINA NST

SIP. NO. 440_/3036/_DINKES / 2014

PAGI : $10.00 \_12.00 \mathrm{WIB}$

SORE : 16.00_20.00 WIB

HARI : $\quad$ TUTUP

Konstruksi tersebut mempunyai dua kesalahan dalam penulisannya. Kesalahan yang pertama yaitu adanya spasi sesudah tanda garis miring. Tanda garis miring dipakai sebagai pengganti kata dan, atau, serta setiap. Seharusnya sebelum dan sesudah tanda garis miring tidak disisipkan spasi karena berdasarkan kaidah ejaan, spasi digunakan setelah tanda seru, tanda tanya, dan tanda titik untuk memulai kalimat baru. Kesalahan yang kedua adalah penggunaan tanda hubung yang pemaknaannya tidak tepat. Tanda hubung tidak dimaknai sebagai sampai denga tetap tanda hubung dipakai untuk menyambung unsur-unsur kata. Seharusnya dapat diganti dengan kata sampai dengan atau dapat disingkat dengan $s . d$ dengan diakhiri tanda titik karena singkatan yang terdiri atas dua huruf yang lazim dipakai dalam surat-menyurat masing-masing diikuti oleh tanda titik (Kemendikbud, 2016:28).

Perbaikannya adalah sebagai berikut.

(5b) PRAKTEK DOKTER GIGI

Drg. ALDELINA NST

SIP. NO. 440/3036/DINKES/2014

PAGI : 10.00 s.d. $12.00 \mathrm{WIB}$

SORE : 16.00 s.d. 20.00 WIB

HARI : TUTUP 


\section{Data 6}

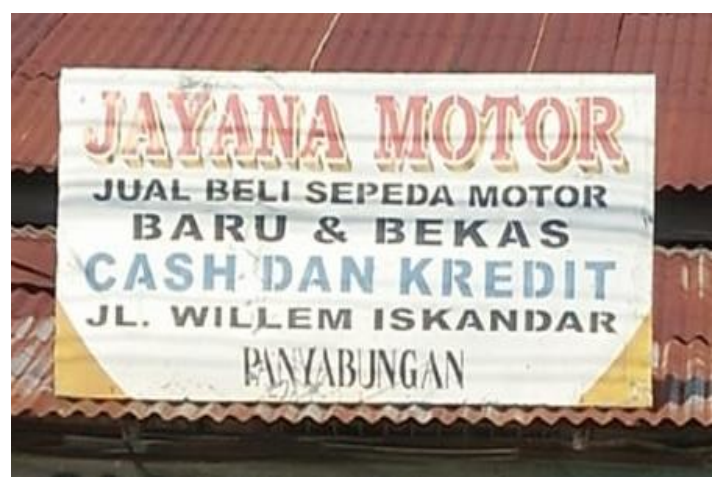

(6a) *JAYANA MOTOR

\section{JUAL BELI SEPEDA MOTOR}

\section{BARU \& BEKAS}

\section{$\underline{\text { CASH DAN KREDIT }}$}

\section{JL. WILLEM ISKANDAR}

\section{PANYABUNGAN}

Konstruksi tersebut mempunyai dua kesalahan dalam penulisannya. Kesalahan yang pertamma yaitu adanya penyerapan bahasa asing yang tidak tepat yang terletak pada kata Cash yang asal katanya berasal dari bahasa inggris. Seharusnya kata-kata asing yang telah diserap ke dalam bahasa Indonesia ditulis sesuai dengan ejaan bahasa Indonesia karena kaidah ejaan, penulisan dan pengucapan unsur-unsur asing disesuaikan dengan kaidah bahasa Indonesia. Bila kata-kata atau istilah asing telah memiliki padanan dalam bahasa Indonesia, seharusnya yang digunakan ialah padanan kata dalam bahasa Indonesia (Rahardian, 2014:152). Kesalahan yang kedua yaitu tidak adanya tanda koma sebagai pemisah antara nama jalan dan wilayah tempat toko. Seharusnya tanda koma diletakkan sesudah nama jalan kemudian dilanjutkan nama tempat karena tanda koma dipakai di antara (a) nama dan alamat, (b) bagian-bagian alamat, (c) tempat dan tanggal, serta (d) nama tempat dan wilayah atau negeri yang ditulis berurutan (Kemendikbud, $2016: 42$ ).

Perbaikannya adalah sebagai berikut.

(6b) JAYANA MOTOR

\section{JUAL BELI SEPEDA MOTOR}

\section{BARU \& BEKAS}

KES DAN KREDIT 
JL. WILLIEM ISKANDAR,

PANYABUNGAN

\section{Data 7}

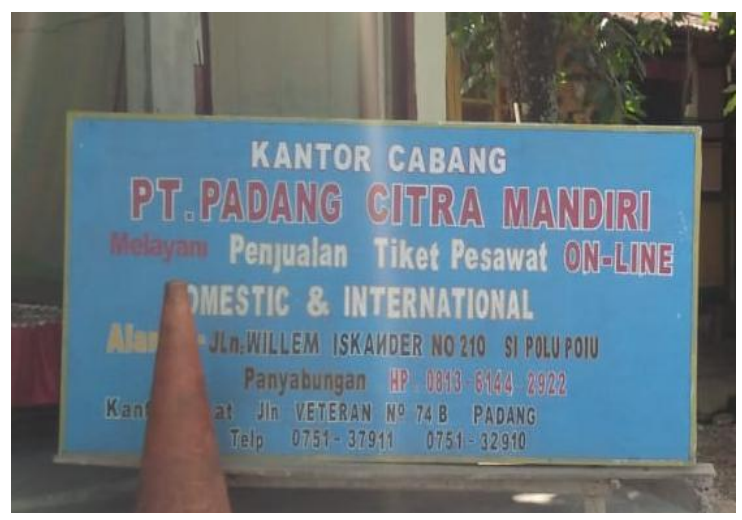

(7a) *KANTOR CABANG

PT. PADANG CITRA MANDIRI

Melayani Penjualan Tiket Pesawat ON-LINE

\section{DOMESTIC \& INTERNATIONAL}

Alamat: JLn. WILLEM ISKANDER NO_210 SIPOLU-POLU

PANYABUNGAN HP 0813-6144-2922

Konstruksi tersebut mempunyai enam kesalahan dalam penulisannya. Kesalahan yang pertama yaitu adanya tanda titik yang diletakkan setelah sinngktatan PT. Seharusnnya Singkatan yang terdiri atas huruf awal setiap kata yang bukan nama diri ditulis dengan huruf kapital tanpa tanda titik (Kemendikbud, 2016:27). Kesalahan yang kedua yaitu kata on-line yang merupakan bahasa asing tidak ditulis dengan huruf miring. Seharusnya disetiap penulisan huruf dalam bahasa asing harus dimiringkan hal ini berdasarkan PUEBI bahwa huruf miring dipakai untuk menuliskan kata atau ungkapan dalam bahasa daerah atau bahasa asing (Kemendikbud, 2016:55-56). Kesalahan yang ketiga yaitu adanya penyerapan bahasa asing pada kata domestic dan international. Seharusnya kata-kata asing yang telah diserap ke dalam bahasa Indonesia ditulis sesuai dengan ejaan bahasa Indonesia karena kaidah ejaan, penulisan dan pengucapan unsur-unsur asing disesuaikan dengan kaidah bahasa Indonesia. Bila kata-kata atau istilah asing telah memiliki padanan dalam bahasa Indonesia, seharusnya yang digunakan ialah padanan kata dalam bahasa Indonesia (Rahardian, 2014:152). 
Kesalahan yang keempat adalah adanya huruf kapital diantara ditengah singkatan JLn seharusnya di huruf $l$ dalam singkatan tersebut dibuat huruf kecil karena seluruh kata dalam kalimat tersebu hanya menggunakan huruf besar diawal katanya. Kesalahan yang kelima yaitu penulisan kata iskander yang tidak tepat, seharusnya diganti dengan kata Iskandar. Kesalahan yang keenam yaitu tidak ada tanda titik setelah penulisan singkatan No. seharusnya singkatan yang terdiri atas dua huruf yang lazim dipakai dalam surat-menyurat masing-masing diikuti oleh tanda titik (Kemendikbud, 2016:28). Kesalahan yang ketujuh yaitu tidak adanya tanda koma antara nama jalan dan wilayah, seharusnya bagian alamat yang disebutkan secara berurutan menggunakan tanda koma karena menurut kaidah ejaan, tanda koma dipakai di antara (a) nama dan alamat, (b) bagian-bagian alamat, (c) tempat dan tanggal, serta (d) nama tempat dan wilayah atau negeri yang ditulis secara berurutan (Sugiarto, 2013:44).

Perbaikannya adalah sebagai berikut.

(7b) KANTOR CABANG

PT PADANG CITRA MANDIRI

Melayani Penjualan Tiket Pesawat Online

DOMESTIK \& INTERNASIONAL

Alamat: Jln. WILLEM ISKANDAR NO. 210, SIPOLU-POLU

PANYABUNGAN HP 0813-6144-2922

\section{Data 8}

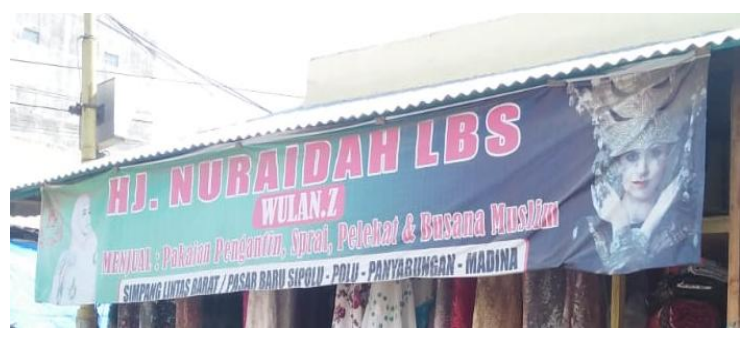

(8a) *HJ. NURAIDAH LBS

MENJUAL: Pakaian Pengantin, Sprai, Pelekat_\& Busana Muslim

SIMPANG LINTAS BARAT/PASAR BARU/SIPOLU-POLU_PANYABUNGAN_MADINA

Konstruksi tersebut mempunyai tiga kesalahan dalam penulisannya. Kesalahan pertama yaitu digunakannya huruf kapital pada kata MENJUAL. Seharusnya kata tersebut tidak 
menggunakan huruf kapital diseluruh hurufnya karena semua kata dalam kalimat tersebut menggunakan huruf kecil dengan huruf kapital diawal katanya karena karena berdasarkan kaidah ejaan huruf kapital dipakai sebagai huruf pertama semua kata di dalam judul buku, majalah, lembaga resmi, termasuk pada papan nama, kecuali kata tugas, seperti dan, oleh, atau, dan untuk (Sugiarto, 2013). Kesalahan yang kedua yaitu tidak adanya tanda koma sebelum kata penghubung dan. Seharusnya tanda koma diletakkan disetiap unsur yang lebih dari dua unsur. Keslahan yang ketiga yaitu digunakannya tanda penghubung untuk memisahkan alamat dan willayah, tanda hubung tidak tepat digunakan dalam kalimat tersebut dan diganti dengan tanda koma karena tanda koma dipakai di antara (a) nama dan alamat, (b) bagian-bagian alamat, (c) tempat dan tanggal, serta (d) nama tempat dan wilayah atau negeri yang ditulis secara berurutan (Sugiarto, 2013:44).

Perbaikannya adalah sebagai berikut.

(8b) HJ. NURAIDAH LBS

Menjual: Pakaian Pengantin, Sprai, Pelekat, \& Busana Muslim

SIMPANG LINTAS BARAT/PASAR BARU/SIPOLU-POLU, PANYABUNGAN, MADINA

\section{Data 9}

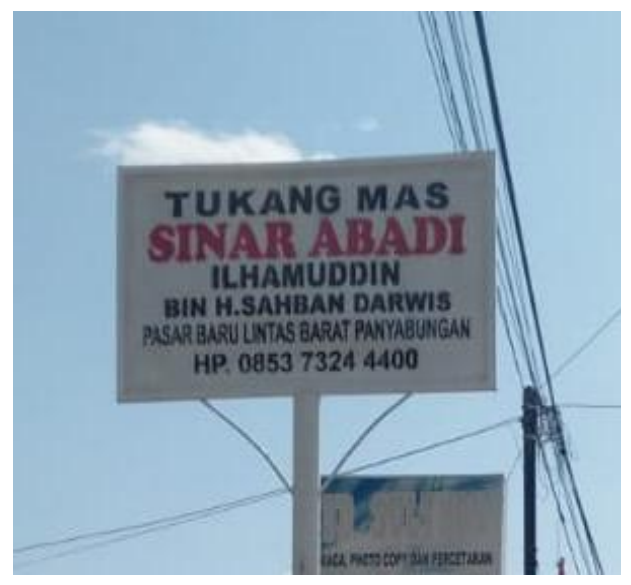

(9a) *TUKANG $\underline{\text { MAS }}$

SINAR ABADI

ILHAMUDDIN 


\section{BIN H.SAHBAN DARWIS}

\section{PASAR BARU LINTAS BARAT PANYABUNGAN}

Konstruksi tersebut mempunyai tiga kesalahan dalam penulisannya. Kesalahan yang pertama yaitu penulisan kata Mas yang merupakan bentuk tidak baku dari kata Emas. Seharusnya kata tersebut diganti dengan kata baku karena penggunaan bahasa yang menggunakan kaidah yang dibakukan atau yang dianggap baku itulah yang merupakan bahasa yang benar (Alwi, 2003:20). Kesalahan yang kedua yaitu tidak adanya spasi setelah tanda titik yang merupakan gelar. Seharusnya spasi disisipkan setelah tanda titik hal ini berdasarkan kaidah ejaan, spasi digunakan setelah tanda seru, tanda tanya, dan tanda titik untuk memulai kalimat baru. Kesalahan yang ketiga yaitu tidak ada tanda koma sebagi pemoisah antara tempat dan wilayah. Seharusnya tanda koma disispkan setelah kata Barat karena tanda koma dipakai di antara (a) nama dan alamat, (b) bagian-bagian alamat, (c) tempat dan tanggal, serta (d) nama tempat dan wilayah atau negeri yang ditulis secara berurutan (Sugiarto, 2013:44).

Perbaikannya adalah sebagai berikut

(9b) TUKANG EMAS

SINAR ABADI

ILHAMUDDIN

BIN H. SAHBAN DARWIS

PASAR BARU LINTAS BARAT, PANYABUNGAN

\section{Data 10}

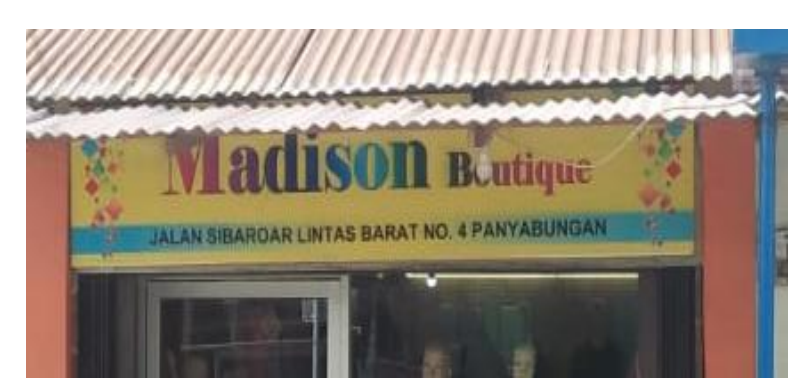

(10a) *MADISON $\underline{\text { Boutique }}$

JALAN SIBAROAR LINTAS BARAT NO. 4_PANYABUNGAN 
Konstruksi tersebut mempunyai tiga kesalahan dalam penulisannya. Kesalahan yang pertama yaitu adanya unsur serapan asing yang digunakan dalam penulisan tersebut yaitu kata Boutique. Seharusnya kata-kata asing yang telah diserap ke dalam bahasa Indonesia ditulis sesuai dengan ejaan bahasa Indonesia karena kaidah ejaan, penulisan dan pengucapan unsurunsur asing disesuaikan dengan kaidah bahasa Indonesia. Bila kata-kata atau istilah asing telah memiliki padanan dalam bahasa Indonesia, seharusnya yang digunakan ialah padanan kata dalam bahasa Indonesia (Rahardian, 2014:152). Kesalahan yang kedua yaitu digunakannya huruf kecil pada kata Boutique dengan huruf kapital diawal katanya. Seharusnya kata tersebut menggunakan huruf kapital diseluruh hurufnya karena semua kata dalam kalimat tersebut menggunakan huruf kapital atau huruf kapitaal diawal katanya saja karena berdasarkan kaidah ejaan huruf kapital dipakai sebagai huruf pertama semua kata di dalam judul buku, majalah, lembaga resmi, termasuk pada papan nama, kecuali kata tugas, seperti dan, oleh, atau, dan untuk (Sugiarto, 2013). Kesalahan yang ketiga yaitu tidak ada tanda koma sebagi pemisah antara nama jalan dan wilayah. Seharusnya tanda koma disispkan setelah nama jalan karena tanda koma dipakai di antara (a) nama dan alamat, (b) bagianbagian alamat, (c) tempat dan tanggal, serta (d) nama tempat dan wilayah atau negeri yang ditulis secara berurutan (Sugiarto, 2013:44).

Perbaikannya adalah sebagai berikut.

(10b) MADISON BUTIK

JALAN SIBAROAR LINTAS BARAT NO. 4, PANYABUNGAN.

\section{Data 11}

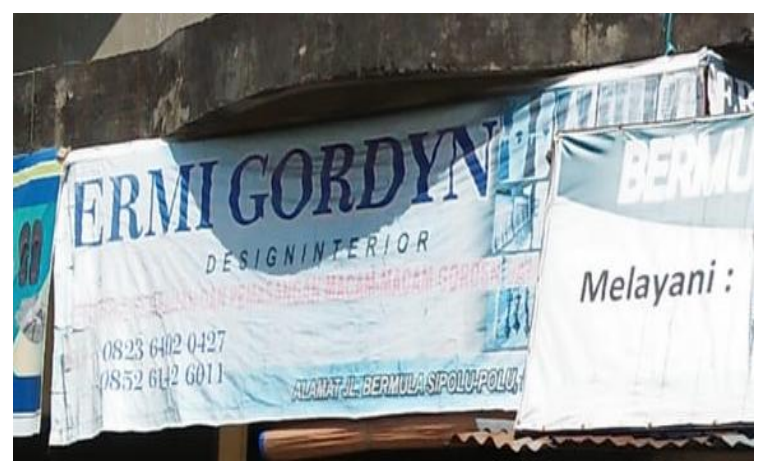

(11a) *ERMY GORDYN

\section{DESIGNINTERIOR}


Konstruksi tersebut mempunyai dua keslahan dalam penulisannya. Keslahan yang pertama yaitu adanya penulisan bahasa asing Design Interior yang tidak dimiringkan penulisannya. Seharusnya disetiap penulisan huruf dalam bahasa asing harus dimiringkan hal ini berdasarkan PUEBI bahwa huruf miring dipakai untuk menuliskan kata atau ungkapan dalam bahasa daerah atau bahasa asing (Kemendikbud, 2016:55-56). Kesalahan yang kedua yaitu tidak adanya penmisah antara kata Design dan Interior, spasi digunakan untuk mengatur jarak antar kata.

Perbaikannya adalah sebagai berikut.

(11b) ERMY GORDYN

DESIGN INTERIOR

\section{E. SIMPULAN}

Berdasarkan hasil penelitian dari hasil analisis data-data media luar ruang di Panyabungan dapat disimpulkan bahwa masih banyak kesalahan-kesalahan penulisan yang terdapat pada media luar ruang tersebut. Bentuk-bentuk kesalahan tersebut berupa diksi/pilihan kata yang kurang tepat, ejaan yang salah seperti tanda baca, pemakaian huruf kapital, penulisan singkatan, garis miring dan lain-lain, dan masih banyak kesalahan yang ditemukan dilapangan.

Hasil penelitian ini menunjukkan bahwa masih banyak orang yang tidak mengerti akan bahasa Indonesia yang baik dan benar terutama dalam penulisan media luar ruang. Karena Bahasa Indonesia wajib digunakan dalam rambu umum, spanduk, dan alat informasi lain yang merupakan pelayanan umum (Rahardian, 2014:153).

\section{F. DAFTAR PUSTAKA}

Alwi, Hasan, dkk. 2003. Tata Bahasa Baku Bahasa Indnesia. Jakarta: Balai Pustaka.

Kementerian Pendidikan dan Kebudayaan. 2016. Pedoman Umum Ejaan Bahasa Indonesia. Jakarta : Badan Pengembangan dan Pembinaan Bahasa.

Rahardian, Ema. 2014. Analisis Penggunaan Bahasa dalam Papan Imbauan di Kabupaten Demak, Volume 10, No 2. Semarang: Balai Bahasa Jawa Tengah.

Setyawati, Nanik. 2010. Analisis Kesalahan Berbahasa Indonesia. Suarakarta: Yuma Pustaka. 
Sugiarto, Eko. 2013. Master EYD Edisi Terbaru. Yogyakarta: Suaka Media.

Susanti, Ratna. 2014. Analisis Kesalahan Berbahasa Pada Penulisan Media Luar Ruang di Kota Klaten, Volume 1, No. 1. Surakarta: Politeknik Indonusa Surakarta 